\title{
Fazer caminho caminhando...
}

\section{Maria Helena Serôdio}

1.

Enquanto revista devotada ao Teatro - na sua enorme diversidade de práticas artísticas de palco - e aos Estudos de Teatro - na sua maior amplitude teórica, histórica e crítica -, a Sinais de cena perfaz agora, com este seu n. ${ }^{\circ}$ 20, dez anos de uma caminhada que vem mantendo com inusual persistência, a par de uma reconhecida qualidade científica e gráfica, de que não tem abdicado.

Tem mantido, efectivamente, um projecto editorial que se reconhece materialmente num mesmo formato (de que não prescinde), a par de uma exigência de rigor e diversidade nos seus conteúdos, que lhe garantem um lugar importante enquanto "crónica abstracta dos tempos" que o shakespeariano Hamlet atribui à arte de que se ocupam as páginas da revista.

Sendo embora uma publicação da Associação Portuguesa de Críticos de Teatro, ela existe numa especial parceria com o Centro de Estudos de Teatro (da Faculdade de Letras da Universidade de Lisboa) e tem vindo a ser apoiada - através de publicidade - pelo Teatro Nacional D. Maria II e pelo Teatro Nacional São João, a que por vezes se junta a Sociedade Portuguesa de Autores: é, naturalmente, merecida e indiscutivel a nossa gratidão a estas instituições. Sem estes apoios institucionais, ou sem a generosa participação de outras instituições na disponibilização de materiais (por parte de Museus, Arquivos, companhias e profissionais de teatro...) e, ainda, sem a colaboração amiga de todos os autores que aqui publicamos, esta revista - simplesmente - não existiria.

0 nosso agradecimento é, de facto, muito sincero. É ainda justo que consideremos estes nossos compagnons de route como fazedores - como nós e connosco - desta publicação de teatro.

\section{2.}

Entretanto, é já no próximo ano, em 2014, que o Centro de Estudos de Teatro (CET) da Faculdade de Letras da Universidade de Lisboa (FLUL) perfaz vinte anos desde a sua criação por Osório Mateus (OM). Encenador, teórico e crítico de teatro, OM (1940-1996) licenciou-se em
Filologia Românica pela Universidade de Coimbra em 1964 e iniciou o seu percurso de docente na FLUL em 1970, tendo-se doutorado por esta Universidade em Literatura Portuguesa com a tese Cinco autos de Vicente: Práticas de reconhecimento, em 1987.

OM marcou de forma decisiva a investigação em teatro no nosso pais e destacou-se, sobretudo, como especialista da obra de Gil Vicente. Na FLUL, fundou em 1980 a cadeira de História do Teatro e, onze anos depois, lançou o Curso de Especialização em Estudos de Teatro, abrindo assim caminho para uma área de investigação, de que veio a derivar uma estrutura mais sólida com a criação posterior do Mestrado e do Doutoramento nessa mesma área do saber, bem como a fundação em 1994 do Centro de Estudos de Teatro.

Tendo deixado o seu espólio de teatro à Biblioteca desta Faculdade, foi, assim, criado o Arquivo Osório Mateus (AOM), um precioso núcleo de documentação para os Estudos de Teatro. Trata-se de um fundo bibliográfico com mais de 15000 espécies dos séculos XVIII a XX, que incluem peças de teatro e estudos sobre teatro em edições, na sua maioria, portuguesas, espanholas, inglesas e francesas. Possui ainda 1000 programas de espectáculos e 300 periódicos de teatro portugueses e estrangeiros, bem como um conjunto importante de imagens de teatro em diferentes suportes (gravura, litografia, fotografia, entre outros).

0 Centro de Estudos de Teatro vem, entretanto, desenvolvendo vários projectos de investigação e criando preciosos instrumentos de estudo a que se acede pelo seu sítio electrónico, como é o caso de importantes bases de dados e conjuntos de documentos, neste caso com ferramentas operativas para os consultar: CETbase (base de dados sobre o Teatro em Portugal), OPSIS (base iconográfica de Teatro em Portugal), CET-e-quinhentos (teatro de autores portugueses do Séc. XVI) e CET-HTP online (documentos para a História do Teatro em Portugal). A estes projectos se adicionou recentemente uma extraordinária reconstrução virtual do Pátio das Arcas (na Lisboa quinhentista), sob a competente e entusiástica 
direcção de José Camões, acessivel pelo link: http://www.youtube.com/watch?v=M5cvaAofTa8.

Por todas estas razões, julgámos importante assinalar - neste número da revista - algumas reflexões em torno do trabalho, que o CET vem promovendo, pelo que a ele dedicamos o "Dossiê temático". Nos vários artigos, que o compõem, é possivel acompanhar algumas das modalidades do trabalho de investigação que o Teatro vem concitando a partir de diversos pontos de vista - teórico, histórico, filológico e analítico - dando prova das potencialidades do campo científico que são os Estudos de Teatro e lembrando o caminho que - por eles - se vem fazendo na FLUL, necessariamente enriquecendo o seu "património" cultural e o seu posicionamento no campo dos Estudos Artísticos.

3.

Memórias do Porto ocupam, neste número da Sinais de cena, o "Arquivo solto", que recupera, pela investigação e escrita de Daniel Rosa, a memória do "Bairro Teatral portuense" oitocentista. E são ainda memórias do teatro na cidade do Porto que o Portefólio nos traz ao recordar o trajecto da companhia que António Pedro dirigiu - o Teatro Experimental do Porto - aqui apresentado por Rui Pina Coelho em texto breve, mas com um conjunto impressivo de imagens de espectáculos realizados ao longo dos sessenta anos da sua importante actividade cultural e artística.

Se a secção "Em rede" nos dá conta de algumas das potencialidades da internet reportando-nos para o actualíssimo "Acervo Mariposa" pela escrita de Bruna Antonelli, "Na Primeira Pessoa" traz-nos um precioso testemunho de vida na entrevista a Norberto Barroca (NB). Com uma carreira longa e muito diversificada - de actor encenador, cenógrafo, dramaturgo, figurinista -, NB recorda aqui momentos importantes do seu percurso, que juntou, na sua formação universitária, a Arquitectura à História e, em termos geográficos, o fez oscilar entre Lisboa e o Porto, com uma passagem não despicienda por Lourenço Marques (hoje Maputo). Foi um dos fundadores da Casa da Comédia, passou pela direcção do Teatro S. Luiz e do TEP, e marcou uma importante viragem do teatro no Porto com as criações que fez com a Seiva Trupe. Compondo um inspirado ciclo de teatro que se situava entre a revista e o cabaré, teve em Um cálice de Porto (1982) um momento inaugural de grande êxito que, de algum modo, se prolongou com Uma familia do Porto (1984) e Os amorosos da Foz (1985).

Numa perspectiva ensaística, os "Estudos aplicados" trazem-nos testemunhos sobre a ópera nos últimos vinte anos em Portugal (por Nuno Fidalgo) e sobre a música teatral oitocentista (no estudo de Isabel Novais), a que se junta uma reflexão sobre a experiência de uma "revisitação" ao Quarteto de Heiner Müller assinalada aqui por Anabela Mendes. Ainda nesta secção, Sebastiana Fadda, sustentandose num aparelho conceptual exigente, debruça-se sobre o espectáculo Chão de água, do Teatro da Terra.

Chegam-nos, entretanto, "Notícias de fora" vindas de Paris (por Marie Plantin), da Argentina (por Alejandro Karasik) e da Roménia, aqui para recordar uma importante homenagem teatral a Georges Banu em Cluj-Napoca, na sua Roménia natal.

No que são as análises de espectáculos neste número (na secção "Passos em volta"), registe-se a variedade de contextos sociais (e geográficos), bem como as propostas que abrangem realidades artísticas diferentes, desde a prática amadora de teatro no Minho (em celebração festiva) até à dança, à performance e, ainda, outras diversas formas de interpelar textos contemporâneos em cena. $E_{1}$ em termos de publicações de teatro e sobre teatro, registese uma nova colecção de peças - Azulcobalto/Teatro -, a referência a mais um livro de memórias de Carmen Dolores e uma biografia de Joaquim Benite.

Face a esta diversificada - mas necessariamente reduzida - amostra do que em teatro e sobre teatro se vem fazendo e pensando entre nós, não podemos ficar indiferentes. Reconhecemos nessa realidade a prova de que vale a pena prosseguir este nosso trabalho para darmos conta de que a arte e a cultura são parte importante - e inalienável - da nossa respiração cultural e fundamento imprescindivel do nosso sentido estético. 